\title{
Theoretical and Experimental Study of Carburisation and Decarburisation of a Meta-Stable Austenitic Steel
}

\author{
Charles West*, Vicente Braz Trindade, Ulrich Krupp, Hans-Jürgen Christ \\ Institut für Werkstofftechnik, Universität Siegen, Germany
}

Received: July 19, 2004; Revised: April 11, 2005

\begin{abstract}
Metastable austenitic stainless steels are known to undergo a partial transformation of austenite to martensite as a consequence of plastic deformation. In the case of cyclic loading, a certain level of plastic strain must be exceeded, and phase formation takes place after an incubation period, during which the necessary amount of plastic deformation is accumulated. The susceptibility of the austenitic phase to deformation-induced martensite formation is strongly affected by the temperature of loading and the stability of austenite, which itself depends on the chemical composition. A key element in this regard is carbon which stabilizes the austenitic phase. It is shown in this study that the carbon concentration can be analysed systematically and reproducible by means of annealing treatments, if the parameters of these treatments are carefully defined on the basis of advanced theoretical thermodynamic and kinetic considerations. First results on the effect of carbon concentration and temperature of fatigue testing on the austenite/martensite transformation are presented, in order to illustrate the significance of these parameters on the martensite formation rate.
\end{abstract}

Keywords: martensitic transformation, carbon concentration, fatigue

\section{Introduction}

\subsection{Background}

This paper considers metallurgical aspects ${ }^{1}$ in preparing solid test specimens with sufficient accuracy to enable a clarified comparison of fatigue test results in support of characterising the deformationinduced martensitic transformation of an austenitic stainless steel AISI 301. The characterisation will investigate specifically the influence of carbon concentration and subzero temperatures on the transformation $^{2,3}$. There are numerous publications which cover aspects of the described martensitic transformation. Literature details which are more specific to the intended investigation include a study investigating subzero test temperatures for deformation-induced martensite to find an optimum combination of strength and residual fatigue for industrial application ${ }^{4}$. Other studies investigate material behavior of transformations in consideration of effects described by the Hall Petch relationship ${ }^{5,6}$ or preferential crystallographic orientation ${ }^{7-9}$, making emphasis of metallurgical aspects. Studies made with regard to material behavior for transformations at and above room temperature under various environmental conditions ${ }^{8,10,11}$ serve to delineate the research area although no direct comparisons are made.

There are various published methods of evaluating the martensite volume fraction in fatigued austenitic stainless steel specimens ${ }^{10,11}$. The most modern of which use SQUID ${ }^{12,13}$ technology in the form of Hall probes and GMR sensors, phase analysis using diffractometry as well as a magnetic induction method.

\subsection{Objectives}

The described phenomenon is based, in this study, on hollow cylindrical test specimens with $2 \mathrm{~mm}$ wall thickness in the gauge length. The specimen geometry in Figure 1 is designed to fulfil the requirements for cyclic fatigue and also to limit the heat treatment duration of carburising or decarburising processes. This is principally achieved through minimizing the cross-section and enlarging the surface area to take-up or release carbon to or from a gas atmosphere at elevated temperatures.
Treating the material at elevated temperatures for long periods result in grain growth ${ }^{5,6}$ and distribution which will influence on the fatigue mechanisms ${ }^{7-9}$. The study objective is to reproducibly modify the carbon content of test specimens with the geometry shown in Figure 1 to three set values of carbon, under consideration of a desired common microstructure after heat-treatment.

\section{Material and Experimental Procedure}

A meta-stable austenitic steel with the designation 1.4310 (AISI 301) was chosen as test material to characterise the change in phase. $\mathrm{Cr}, \mathrm{Fe}$, $\mathrm{Ni}$ and $\mathrm{C}$ are the main constituents of the material shown in Table 1. $\mathrm{Ni}$ and $\mathrm{Mn}$ stabilize the fcc phase, whereas $\mathrm{Cr}$ and Mo are accountable for corrosion resistance.

At a heat treatment temperature of $1050{ }^{\circ} \mathrm{C}$, even at low oxygen partial pressures in the treatment apparatus the development of chromium oxide $\left(\mathrm{Cr}_{2} \mathrm{O}_{3}\right)$ on the specimen surface is unavoidable, due to the very low oxygen partial pressure in equilibrium between $\mathrm{Cr}$ and chromium oxide ${ }^{14}\left(\mathrm{Cr}_{2} \mathrm{O}_{3}\right)$. Chromium oxide $\left(\mathrm{Cr}_{2} \mathrm{O}_{3}\right)$ on the surface, acts as a barrier to the diffusion of carbon. To avoid the formation of a barrier layer, the specimens were coated with nickel. The austenitic specimens were coated galvanically ${ }^{15}$ in a solute which consists of $\mathrm{NiSO}_{4}, \mathrm{NH}_{3} \mathrm{SO}_{4}$ and $\mathrm{KCl}$. Adhesion test results defined a specimen surface roughness of $27 \mu \mathrm{m}$ and a charge of $40 \mathrm{~mA} / \mathrm{cm}^{2}$ as the most favourable parameters for reproducible coatings. The stability of nickel oxide raises the allowable oxygen partial pressure to $1 \times 10^{-6} \mathrm{bar}^{14}$ at $1050{ }^{\circ} \mathrm{C}$ which is well within the realms of practicality whilst preparing the heat-treatment apparatus. The recipient was held in a vacuum below $1 \times 10^{-7}$ bar in the warm-up phase of the vertical furnace before the gas mixture flooded the chamber to a pressure slightly above atmospheric pressure. Initial heat-treatments were carried out on $2 \mathrm{~mm}$ thick discs before being carried out on cylindrical test specimens of the geometry shown in Figure 1. The grain 
size of specimens was determined using the linear intercept method in conjunction with a logarithmic Gauss distribution.

Cyclic mechanical tests were performed on a hydraulic test bench under total strain control and zero mean strain. Values of strain amplitude used in the investigation include 0.5 and $0.85 \%$. Using these values, a test plan was drawn for the fatigue of test specimens with carbon concentrations of $0.04,0.07$ and 0.09 wt. (\%). A further extension to the test plan is the variation in test temperature below the initial temperature of $22{ }^{\circ} \mathrm{C}$ using a temperature chamber to set temperatures of $-50{ }^{\circ} \mathrm{C}$ and $100{ }^{\circ} \mathrm{C}$.

The volume fraction of martensite was measured by a probe using a magnetic induction method. The magnetic induction is the sum of the applied field and the external field that arises when the probe is brought into contact with ferromagnetic material. This increase in magnetization can be measured by the magnetic permeability and is given as a digital read-out in percentage volume fraction. To gain comparative volume fractions for the test specimens in fatigue, tests were held after specific fatigue cycles so that measurements could be made at room temperature and zero load.

\section{Results and Discussion}

\subsection{Thermodynamic calculations}

Carbon has a strong influence on the transformation of austenite to martensite in austenitic steels. The carbon content of steel can be varied using heat treatments and the most popular method of carburisation and decarburisation is to use a gas-mixture of methane $\left(\mathrm{CH}_{4}\right)$ and hydrogen $\left(\mathrm{H}_{2}\right)$ at elevated temperatures. The fundamental principle of using these gases is described in the stoichiometric equation,

$$
\mathrm{C}+2 \mathrm{H}_{2} \Leftrightarrow \mathrm{CH}_{4}
$$

The carbon directly influencing the martensitic transformation is that which is dissolved in fcc austenite. In order to attain the desired carbon content in the test specimens it is necessary to analyse the heat treatment temperature at which carbon will diffuse to or from the gas environment for carburisation and decarburisation respectively. The rate and direction of the diffusion is dictated by the difference in carbon activities between the solid and gas phases. The carbon activity in the gas phase can be calculated using the equation

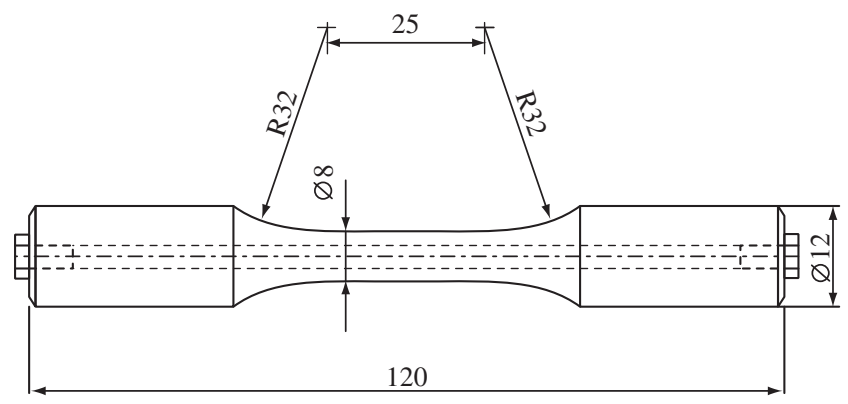

Figure 1. Test specimen geometry.

$$
a_{C}=K \cdot \frac{p_{C H 4}}{\left(p_{H 2}\right)^{2}}
$$

where $\mathrm{p}_{\mathrm{CH} 4}$ and $\mathrm{p}_{\mathrm{H} 2}$ are partial pressures of methane and hydrogen in the gas mixture. Using solely hydrogen to decarburise a specimen would give an activity of zero, whereby using solely methane would result in a decomposition of the gas ${ }^{16}$ to an activity above one. $\mathrm{K}$ is the temperature dependant chemical reaction equilibrium constant. The value of $\mathrm{K}$ is written as a function of temperature ${ }^{17}$ as

$$
\lg K(T)=4649 / T-5.672
$$

A computer program called FactSage has been utilised to investigate thermodynamic equilibrium between solid and gas phases for different combinations of gas partial pressures for a total pressure of 1 bar. Their influence on thermodynamic equilibrium is observed as carbon activity in the gas phase at different temperatures. Different type of carbides are stable, depending on the carbon activity in the gas phase.

In order to allow for a comparison of simulation results with experimental observations, a distinction is made between carbon content which refers to carbon dissolved in the fcc and the carbon content precipitated in the form of carbides. Figure 2. presents the simulation results of thermodynamic equilibrium at a temperature

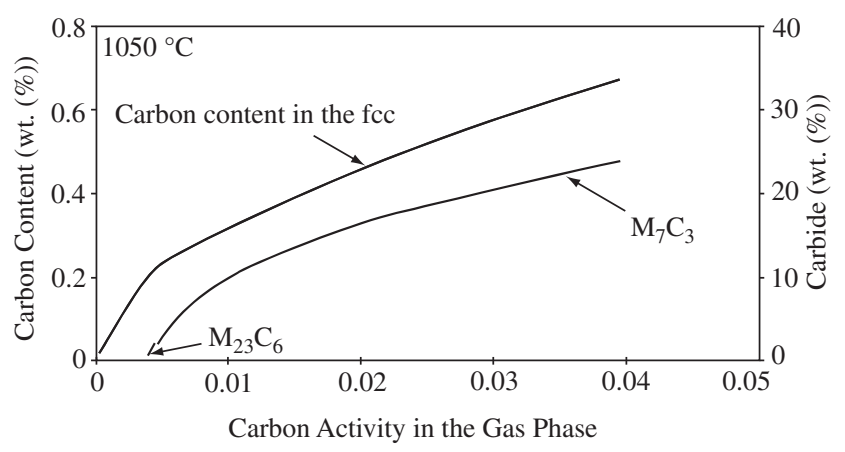

(a)

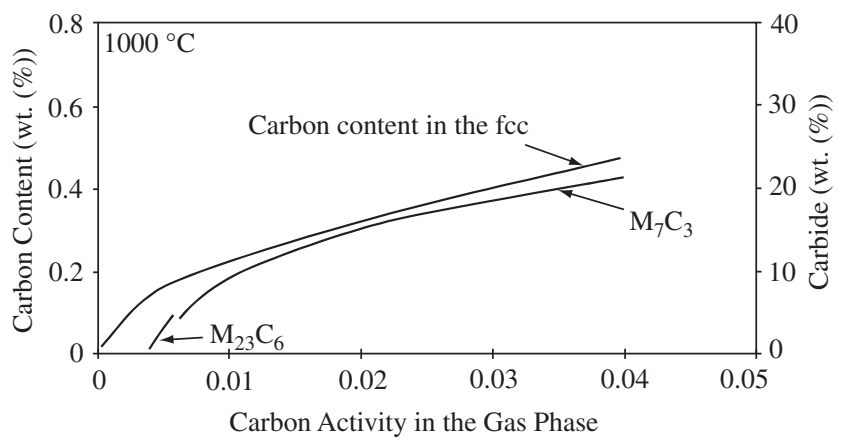

(b)

Figure 2. Thermodynamic equilibrium calculation at different temperatures using the commercial software FactSage: a) $1050{ }^{\circ} \mathrm{C}$; and b) $1000{ }^{\circ} \mathrm{C}$.

Table 1. Nominal chemical composition (in wt. (\%)) of the used austenitic steel.

\begin{tabular}{lllllllll}
\hline Elements & $\mathrm{C}$ & $\mathrm{Si}$ & $\mathrm{Mn}$ & $\mathrm{P}$ & \multicolumn{1}{c}{$\mathrm{S}$} & $\mathrm{Cr}$ & $\mathrm{Ni}$ & $\mathrm{M}$ \\
\hline wt. $(\%)$ & 0.108 & 0.98 & 1.278 & 0.027 & 0.005 & 16.8 & 7.41 & $\mathrm{~B}$ \\
Elements & $\mathrm{Cu}$ & $\mathrm{Al}$ & $\mathrm{Ti}$ & $\mathrm{V}$ & $\mathrm{Nb}$ & $\mathrm{Zr}$ & $\mathrm{C}$ \\
wt. $(\%)$ & 0.086 & 0.033 & 0.007 & 0.043 & 0.016 & 0.007 & $<.0001$ \\
Elements & $\mathrm{W}$ & $\mathrm{Mg}$ & $\mathrm{Sn}$ & $\mathrm{Ta}$ & $\mathrm{Ca}$ & $\mathrm{Fe}$ & & \\
wt. $(\%)$ & 0.07 & 0.0005 & 0.01 & 0.01 & 0.0018 & 72.736 & \\
\hline
\end{tabular}


of $1050{ }^{\circ} \mathrm{C}$ and $1000{ }^{\circ} \mathrm{C}$ for carbon activities in the gas phase from 0 to 0.05 . There are carbide transition points in each of the diagrams presented in Figure 2 where $\mathrm{M}_{23} \mathrm{C}_{6}$ transforms to $\mathrm{M}_{7} \mathrm{C}_{3}$. They lie at carbon activities of 0.0045 and 0.006 for temperatures of $1050{ }^{\circ} \mathrm{C}$ and $1000{ }^{\circ} \mathrm{C}$ respectively.

For a carbon activity in the gas phase of 0.48 at a temperature of $1050{ }^{\circ} \mathrm{C}$, the theoretical carbon content in the fcc matrix rises to a maximum of $3.56 \mathrm{wt}$. (\%). This translates to a carbon content value after consideration of the carbon in carbide $\left(\mathrm{M}_{7} \mathrm{C}_{3}\right)$ to $7.4 \mathrm{wt}$. $(\%)$ in total, before the value decreases as cementite is formed.

In order to determine the heat treatment durations, the diffusion of carbon into both sides of a flat specimen of $2 \mathrm{~mm}$ is calculated. The diffusion coefficient of carbon ${ }^{18}$ of $2.6472 \times 10^{-11} \mathrm{~m}^{2} / \mathrm{s}$ at $1050{ }^{\circ} \mathrm{C}$ is used for the austenitic steel in the calculation. In Figure 3, the minimum durations of diffusion processes are presented from an analytical calculation method which utilises a trigonometric series.

The method shows good correlation between calculated and practical results with regard to duration times with the exception of extended decarburisation. In comparison to practical results using a $2 \mathrm{~mm}$ thick disc specimen, a carbon content as low as $0.04 \mathrm{wt}$. (\%) is achieved from an initial content of 0.108 wt. (\%) in 20 hours of decarburisation at a temperature of $1050{ }^{\circ} \mathrm{C}$.

Experimental results of cylindrical hollow specimens gave carbon concentrations of $0.09,0.07$ and $0.04 \mathrm{wt}$. (\%) for respective durations of 5, 10 and 20 hours in a hydrogen-helium gas atmosphere at $1050{ }^{\circ} \mathrm{C}$. Heat treatment duration was extended to 40 hours in an effort to minimise the carbon content in the specimens. Extended duration gave a negligible change in minimising carbon content and this could be attributed to the slow diffusion of oxygen through the nickel coating to the nickel to base-metal interface. Existing, insoluble carbides of the elements $\mathrm{Ti}, \mathrm{Nb}, \mathrm{Zr}$ and $\mathrm{Si}$ were also theoretically considered as an explanation for the remainder of carbon in the specimen but they only accounted for 0.005 wt. (\%) carbon. Durations above that of the minimum achievable decarburisation of specimens helped to ensure that the carbon remainder is uniformly distributed in the fcc austenite.

In comparison to austenitic-ferritic steels, the carbon solubility of a meta-stable austenite is much lower ${ }^{1}$. Carburising the material will lead to carbides forming in the grain and at the grain boundaries which is detrimental to mechanical properties and furthermore to the comparability of mechanical tests. Figure 4 shows the undesirable development of carbides forming at the grain boundaries and in the worst case simulated, the formation of cementite.

The high amount of carbides at the grain boundaries and in the grain would severely affect material properties in fatigue and lead to misinterpretation of results. To avoid this problem individual test specimens need only be decarburised to give the required span of results to support the final characterization. The relatively high initial

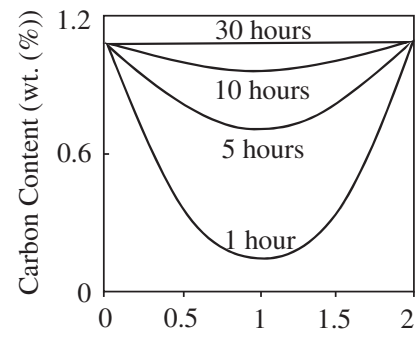

Specimen Thickness ( $\mathrm{mm})$

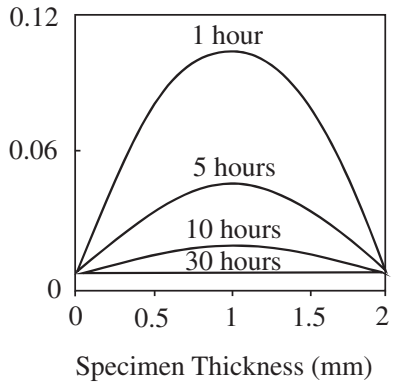

Figure 3. Calculated carbon profile across a $2 \mathrm{~mm}$ thick specimen of austenitic steel for different durations for: a) carburisation; and b) decarburisation. value of carbon concentration of 0.108 wt. (\%) for stainless steels, in the as-received condition, is in close proximity to the maximum carbon solubility in the fcc phase of $0.12 \mathrm{wt}$. (\%) for a heat treatment at $1050{ }^{\circ} \mathrm{C}$, without detectable carbides. Consequent values of carbon
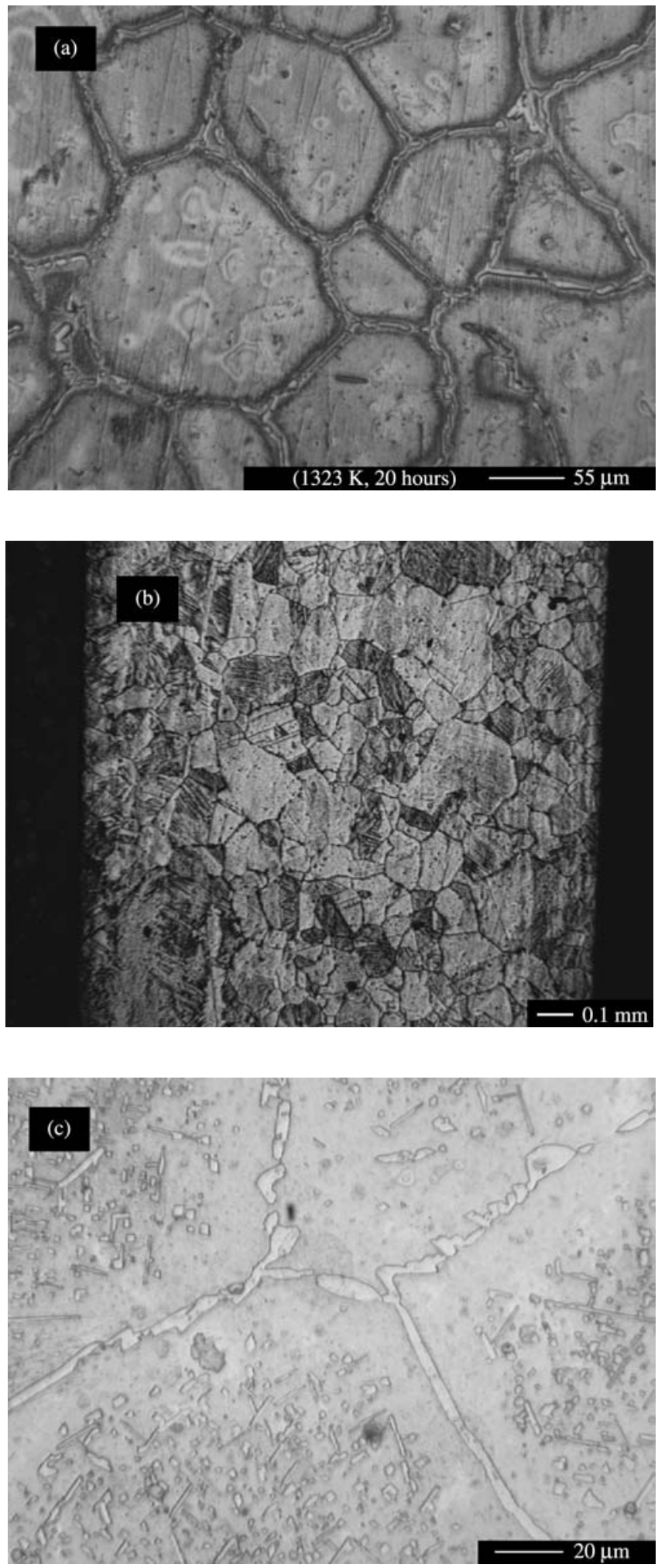

Figure 4. a) Carbides $\left(\mathrm{M}_{7} \mathrm{C}_{3}\right.$ and $\left.\mathrm{M}_{23} \mathrm{C}_{6}\right)$ at the grain boundaries after 20 hours; b) Cementite in the grain after 40 hours; and c) Carbides $\left(\mathrm{M}_{7} \mathrm{C}_{3}\right.$ and $\left.\mathrm{M}_{23} \mathrm{C}_{6}\right)$ and cementite in the grain and at the grain boundaries after 40 hours. 
content which need to be reproducibly attained in test specimens are 0.04, 0.07 and 0.09 wt. (\%).

Figure 5a presents the inhomogeneous microstructure of a decarburised specimen with no visible carbides. In Figure $5 b$ the fatigued microstructure of a decarburised specimen is presented where martensite can be seen in the form of darkened grains.

The test material in its as-received condition has a mean grain size of $35 \mu \mathrm{m}$ and a deformation induced martensite volume fraction of $6 \%$. In evaluating the effects of heat treatment duration on grain growth, both mean grain size as well as standard deviation are observed. As shown in Figure 6, at a temperature of $1000{ }^{\circ} \mathrm{C}$ and durations of 50 hours and 100 hours, the grain size increases from $30 \mu \mathrm{m}$ to $60 \mu \mathrm{m}$ with respective standard deviations of $20 \mu \mathrm{m}$ and $40 \mu \mathrm{m}$. A constant standard deviation of $50 \mu \mathrm{m}$ is reached at $1000{ }^{\circ} \mathrm{C}$ from 200 hours to the maximum evaluated duration of 350 hours.

In comparison, at an elevated temperature of $1050{ }^{\circ} \mathrm{C}$ for durations of 50 hours and 100 hours the mean grain size increases from $60 \mu \mathrm{m}$ to $70 \mu \mathrm{m}$ and displays a constant standard deviation of $50 \mu \mathrm{m}$ for the period. It appears that available space in the microstructure is utilised in primary recrystallization at a maximum mean grain size of $70 \mu \mathrm{m}$ and an equivalent standard deviation of $50 \mu \mathrm{m}$ before secondary recrystallization commences. As a response to the described findings in investigating grain growth, heat-treatment durations of
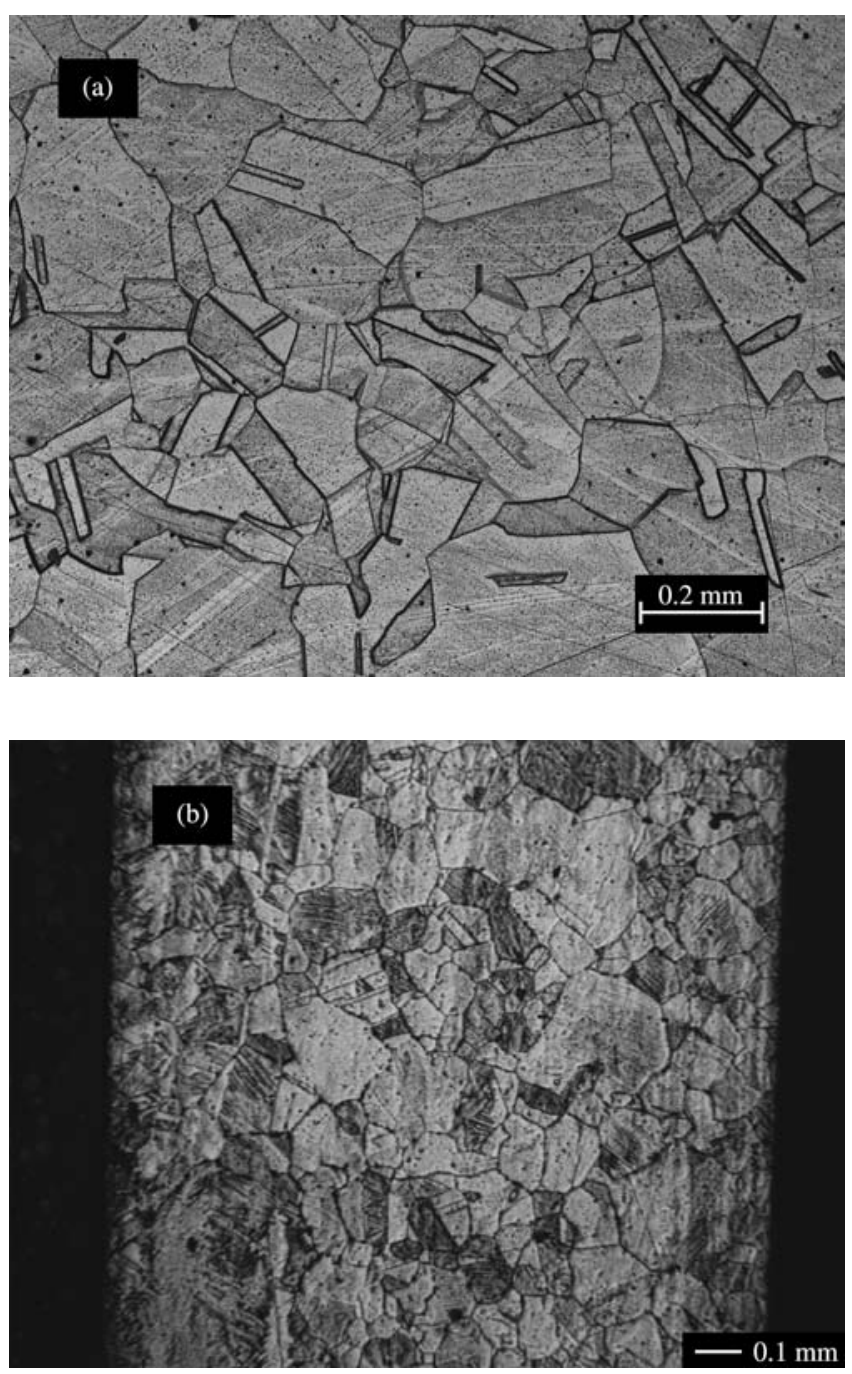

Figure 5. a) Annealed austenitic steel microstructure; and b) austenite with martensite formation after fatigue test. all test specimens, regardless of their individual carbon concentrations, are held above 50 hours. This would mean that after 20 hours of decarburising the decarburising gas will seize to flow and allow the carbon concentration to level across the specimen cross section for the remaining period.

\subsection{Mechanical properties}

A number of fatigue tests were performed, at room temperature, on specimens in the as-received condition of $0.108 \mathrm{wt}$. (\%) carbon. Their results helped specify the total strain amplitudes best suited for the characterisation of the martensitic transformation with respect to a variation in carbon and test temperature. The preliminary tests are presented in Figure 7a and show that with an original martensite volume fraction of $6 \%$ and a high value of carbon content, a total strain amplitude of $0.9 \%$ is needed to harden the material and conse-

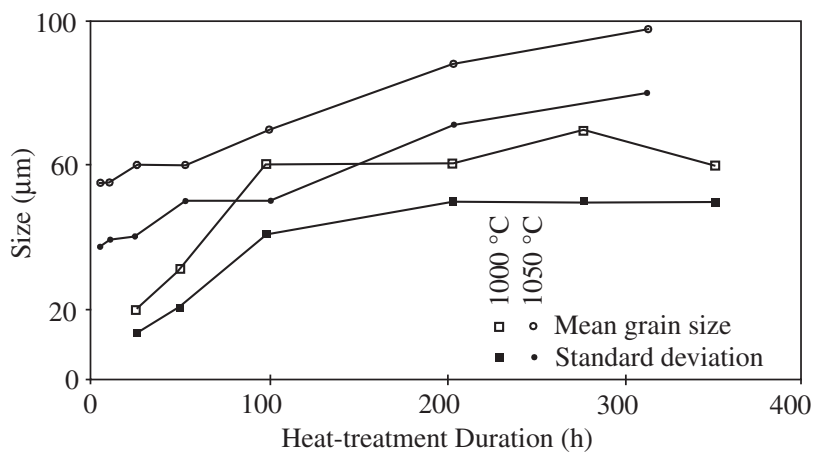

Figure 6. Mean grain size and standard deviation.

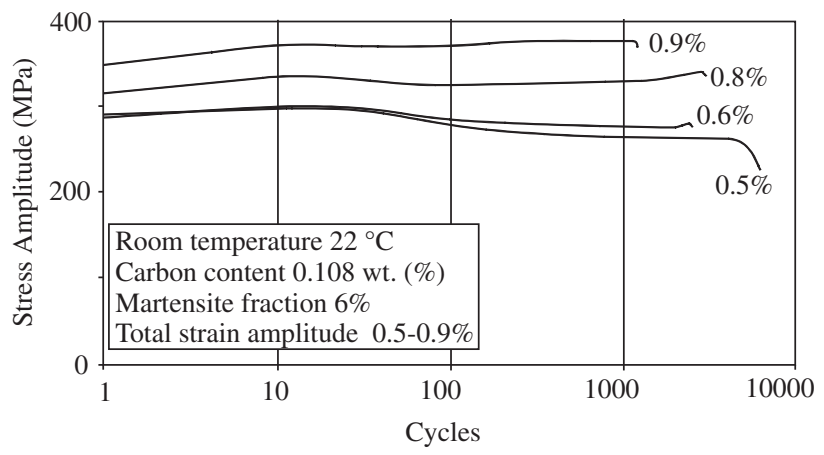

(a)

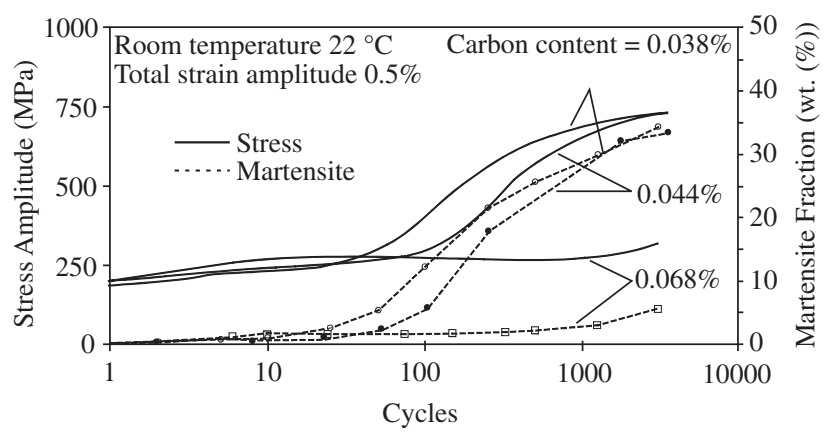

(b)

Figure 7. a) Influence of total strain amplitude on test specimens in the asreceived condition; and b) Influence of carbon content at a constant strain amplitude. 
quently increase the volume fraction of martensite in the specimen. Values of $0.5 \%$ and $0.85 \%$ total strain amplitude are chosen for the continued tests and characterisation because they represent values at which the material respectively softens and hardens (see Figure 7a). Any variation in the carbon content below 0.108 wt. (\%) or test temperature below $22{ }^{\circ} \mathrm{C}$ will cause the martensite volume fraction to increase relative to results presented in Figure $7 \mathrm{a}$ when the test specimen is fatigued. Figure $7 \mathrm{~b}$ presents the results of a variation in carbon content from 0.038 wt. (\%) to 0.068 wt. (\%). The heavy influence of carbon concentration on material hardening is evident by comparison with test specimens of 0.108 wt. (\%) (see Figure 7a). In Figure $7 \mathrm{~b}$ it is shown that a small difference in carbon content, as from 0.038 to $0.044 \mathrm{wt}$. (\%), will influence the materials affinity to transform to martensite.

Figure 8 shows the influence of total strain amplitude at constant temperature and consistent carbon content. At room temperature, as a result of decarburising the material to $0.038 \mathrm{wt}$. (\%) carbon content, the stress level through hardening has reached almost $1000 \mathrm{MPa}$.

The influence of test temperature on the martensitic transformation of test specimens with a relatively high carbon content is depicted in Figure 9. The specimens all have a carbon content of 0.09 wt. (\%) which prevents the material from hardening at room temperature. Lowering the test temperature to sub-zero temperatures instantaneously increases the flow stress throughout fatigue. Once stress saturation level is reached there is no further change in martensite volume fraction.

\section{Summary}

- The reproducibility of decarburising test specimens to set values of carbon content is dependant preferentially on the quality of nickel coating. An analysis of the galvanically coated specimens, using adhesion tests, has shown the specimen surface

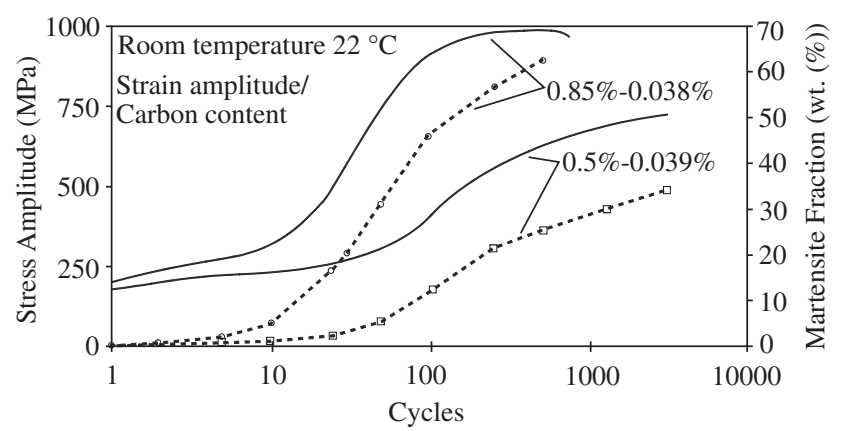

Figure 8. Influence of total strain amplitude on decarburised test specimens.

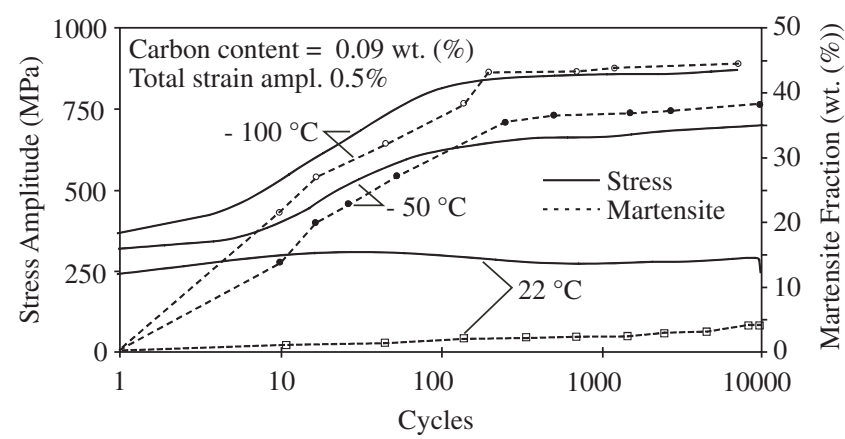

Figure 9. Influence of temperature on test specimens of relatively high carbon content at a constant strain amplitude. roughness of $27 \mu \mathrm{m}$ and current of $40 \mathrm{~mA} / \mathrm{cm}^{2}$ in a galvanic cell to be most suitable.

- Carbon content values of 0.04, 0.07 and 0.09 wt. (\%) are attained reproducibly through decarburising nickel-coated specimens of an austenitic stainless steel with the designation 1.4301 (AISI 301) in a hydrogen-helium gas atmosphere at a temperature of $1050{ }^{\circ} \mathrm{C}$.

- An analysis of the microstructures of heat-treated specimens for different treatment durations gave a variation in mean grain size in relation to constant standard deviation above 200 hours duration at $1000{ }^{\circ} \mathrm{C}$ and between 50 and 100 hours at $1050{ }^{\circ} \mathrm{C}$. The results may be interpreted that the microstructure undergoes primary recrystallization before the standard deviation increases with mean grain size as secondary recrystallization commences.

- As a result of different test temperatures and carbon content of test specimens, the mechanical tests show a broad span of results for the characterisation of the martensitic transformation. A change in martensite formation is clearly identifiable for a change in carbon content of just $0.006 \mathrm{wt}$. (\%).

\section{Acknowledgments}

This research is funded by the Deutsche Forschungsgemeinschaft and the funded fellowship of the author V. B. Trindade from the Brazilian Research foundation (CAPES) is gratefully acknowledged.

\section{References}

1. Padilha AF, Rios PR. Decomposition of austenite in austenitic stainless steels. ISIJ International. 2002; 42(4):325-337.

2. Krupp U, Christ HJ, Lezuo P, Maier HJ, Teteruk RG. Influence of carbon concentration on the martensitic transformation in metastable austenitic steels under cyclic loading conditions. Mater. Sci. Eng. 2001; A319-321:527.

3. Krupp U, West CG, Duan H, Christ HJ. Strain-induced martensite formation in metastable austenitic stainless steels with varying carbon content. Zeitschrift für Metallkunde. 2002; 7:706-711.

4. Maier HJ, Donth B, Bayerlein M, Mughrabi H, Meier B, Kesten M. Optimierte Festigkeitssteigerung eines metastabilen austenitischen Stahles durch wechselverformungsinduzierte Martensit-Umwandlung bei tiefen Temperaturen. Z. Metallkd. 1993; 84:820-826.

5. Ganesh Sundara Raman S, Padmanabhan KA. Influence of martensite formation and grain size on room temperature low cycle fatigue behavior of AISI 304LN austenitic stainless steel. Mater. Sci. Technol. 1994; 10:614-620.

6. Singh KK. Sangal S, Murty GS. Hall-petch. behavior of 316L austenitic stainless steel at room temperature. Mater. Sci. Technol. 2002; 18(2):165-172.

7. Mineur M, Villechaise P, Mendez J. Influence of the crystalline texture on the fatigue behavior of a $316 \mathrm{~L}$ austenitic stainless steel. Mater. Sci. Eng. 2000; A286:257-268.

8. Alain R, Violan P, Mendez J. Low cycle fatigue behavior in vacuum of a 316L type austenitic stainless steel between 20 and $600^{\circ} \mathrm{C}$. Mater. Sci. Eng. 1997; A229:87-94.

9. Morrison DJ. Influence of grain size and texture on the cyclic stress-strain response of nickel. Mater. Sci. Eng. 1994; A187:11-21.

10. Nebel T, Martin U, Eifler D. Wechselverformungsverhalten metastabiler austenitischer Stähle. HTM. 2001; 56(5):314-320.

11. Bassler HJ, Eifler D. Cyclic deformation behavior and plasticity-induced martensite formation of the austenitic stainless steel X6CrNiTi1810. In: Wu XR, Wang ZG, editors. Fatigue '99: Proceedings of $7^{\text {th }}$ International Fatigue Congress; 1999; Beijing, P. R. China; 1999. p. 205-210

12. Bassler H-J, Eifler D, Lang M, Dobmann G. Characterisation of the fatigue behavior of austenitic stainless steel using HTSL-SQUID. In: 
Thompson DO, Chimenti DE, editors. $24^{\text {th }}$ Annual Review of progress in Quantitative Non-Destructive Evaluation; 1997 July 27-August 1; San Diego, California: Plenum Press; 1997. p. 1597-1604

13. Lang M, Johnson J, Bassler H-J. Fatigue Characterisation of AISI 321 austenitic steel by means of magnetic materials characterisation using HTSL-SQUID. In: Proceedings of COFREND Congress; 1997; Nantes. 1997. p. 621.

14. Richardson FD, Jeffes JHE. The thermodynamics of substances of interest in iron and steel making from $0{ }^{\circ} \mathrm{C}$ to $2400{ }^{\circ} \mathrm{C}$. J. Iron Steel Inst. 1948; 160:261-270.

15. Berchtold L. Wechselwirkung von Reaktorwerkstoffen unter besonder Berücksichtiger Verformung [dissertation]. University of Erlangen; 1983.
16. Christ H-J. Experimental characterization and computer based description of the carburisation behavior of austenitic stainless steel AISI 304L. Mater. Corrosion. 1998; 49:258-265.

17. Barin I, Knacke O, Kubaschewski O. Thermochemical properties of inorganic substances. Berlin: Springer; 1973.

18. Agarwala RP, Naik MC, Amand MS, Paul AR. Diffusion of carbon in stainless steel. Journal of nuclear material. 1970; 36(1):41-47.

19. Kubaschewski O, Alcock CB. Metallurgical Thermochemistry. 5. ed. Oxford: Pergamon Press; 1979.

20. Kubaschewski O, Alcock CB, Spencer PJ. Materials Thermochemistry. 6. ed. Oxford: Pergamon Press; 1993. 